\title{
CONTROLS ON THE RADIOCARBON RESERVOIR AGES IN THE MODERN DEAD SEA DRAINAGE SYSTEM AND IN THE LAST GLACIAL LAKE LISAN
}

\author{
Reuven Belmaker ${ }^{1,2} \bullet$ Mordechai Stein $^{3} \bullet$ Yoseph Yechieli $^{3} \bullet$ Boaz Lazar $^{1}$
}

\begin{abstract}
Carbon isotopic and chemical compositions of freshwaters feeding the Dead Sea and the Sea of Galilee (i.e. perennial streams and floods along their stream profiles) were used to constrain the factors that dictate the reservoir ages (RA) of these lakes and the last glacial Lake Lisan. Runoff waters are characterized by high $\mathrm{Ca}^{2+}, \mathrm{Mg}^{2+}$, alkalinity, and radiocarbon contents (67-108 pMC), suggesting a major role for ${ }^{14} \mathrm{C}$ atmospheric exchange reactions (carbonate rock dissolution alone will result in lower pMC values). These exchange processes were corroborated by dissolved inorganic carbon (DIC) and $\delta^{13} \mathrm{C}$ trends throughout the flood profile. During the evolution from rain to incipient runoff, the ${ }^{14} \mathrm{C}_{\mathrm{DIC}}$ of the water increases and is accompanied by a DIC increase and $\delta^{13} \mathrm{C}_{\mathrm{DIC}}$ decrease, suggesting an addition of soil $\mathrm{CO}_{2}$, which is characterized by light $\delta^{13} \mathrm{C}$ and high ${ }^{14} \mathrm{C}$ content. When incipient runoffs evolve to floods, the opposite trends are observed.
\end{abstract}

It appears that the Sea of Galilee, the Dead Sea, and its last glacial precursor, Lake Lisan, maintained uniform but specific RAs of $0.8 \pm 0.1,2.3 \pm 0.1$, and $1.6 \pm 0.3 \mathrm{kyr}$, respectively. However, applying the ${ }^{14} \mathrm{C}$ contents of modern Dead Sea water sources to the water mass balance of Lake Lisan reveals that the RA of Lake Lisan is higher than that predicted by the mass balance. This discrepancy may reflect enhanced dissolution of carbonatic dust, changes in the amount of ${ }^{14} \mathrm{C}$ exchanged in Judean Desert floods, or variations in the contribution of brine and saline springs. Furthermore, the small fluctuations in the Lisan RA $(1.6 \pm 0.3 \mathrm{kyr})$ may reflect small, short-term changes in the relative contributions of these sources.

\section{INTRODUCTION}

Radiocarbon dating of primary carbonates deposited in late Quaternary lakes that occupied the Dead Sea basin (the last glacial Lake Lisan, the Sea of Galilee, and the Holocene Dead Sea; see Figure 1) requires knowing the ${ }^{14} \mathrm{C}$ content of the lakes' water. The deviation of this value (the ${ }^{14} \mathrm{C}$ content) from the atmospheric ${ }^{14} \mathrm{C}$ equilibrium can be defined as the reservoir age (RA) (Stein et al. 2004; Bookman et al. 2007). The RA may reflect several mechanisms: the "hard water effect" (caused by old carbonate dissolution), exchange between the ${ }^{14} \mathrm{C}$ dissolved in the water and the contemporaneous atmospheric $\mathrm{CO}_{2}$, mixing of water sources of different RAs, and aging within the lake reservoir.

The water bodies in the Dead Sea basin show significant variations in their RAs: the high stand of the last glacial Lake Lisan (26-18 kyr BP) yielded values of $\sim 1.6 \pm 0.3 \mathrm{kyr}$ (obtained by the difference between primary aragonite and contemporaneously deposited organic debris). The late Holocene Dead Sea yielded a higher RA of 2.4-2.2 kyr (Talma et al. 1997; Stein et al. 2004; Bookman et al. 2007). Contemporaneous aragonite-organic debris pairs from the late Pleistocene Sea of Galilee, along with modern aragonite-water values from the lake, yield an RA of $\sim 0.8 \mathrm{kyr}$ (Hazan et al. 2005; Lev et al. 2007). Moreover, previous studies have shown that the RA varies considerably between the water sources of the lakes (e.g. Carmi et al. 1985; Talma et al. 1997).

In this study, we examine the mechanisms that control the variations in the RA of these lakes and their water sources. For this, we analyzed the ${ }^{14} \mathrm{C}$ activity and $\delta^{13} \mathrm{C}$ of dissolved inorganic carbon in the water $\left({ }^{14} \mathrm{C}_{\mathrm{DIC}}\right.$ and $\delta^{13} \mathrm{C}_{\mathrm{DIC}}$, respectively), as well as the chemical composition in the various freshwater sources of the lakes (i.e. rain, incipient runoff, floods, and perennial streams).

\footnotetext{
'Institute of Earth Sciences, Hebrew University, Jerusalem, Israel 91904.

${ }^{2}$ Corresponding author. Email: ruvke@pob.huji.ac.il.

${ }^{3}$ Geological Survey of Israel, Jerusalem, Israel 95501.
} 
Figure 1 Map of sampling sites. The maximum extent of Lake Lisan is marked in dark gray. Sampling sites are as follows: 1) Meshushim River; 2) Yarmouk River; 3) Jordan River at Arik bridge; 4) Jordan River at Pkak bridge; 5) Jordan River at Yosseph bridge; 6) Dan spring and river; 7) Wadi Zeelim; 8) Wadi Hever; 9) Arugot and David wadis; 10) Wadi Darga; 11) Wadi Kidron; 12) Jerusalem; 13) Eshtaol.

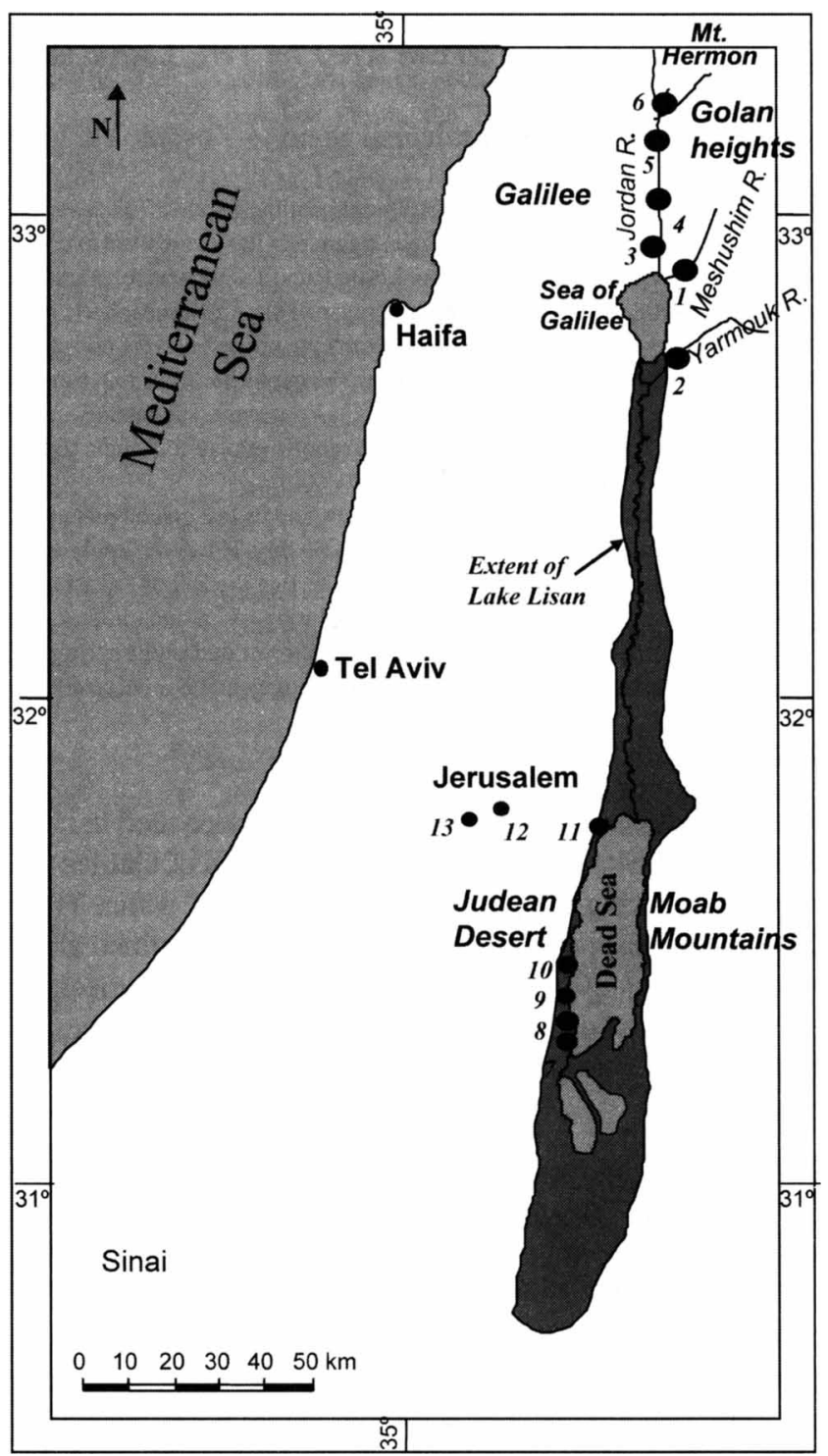

\section{WATER SOURCES OF THE MODERN DEAD SEA}

The modern Dead Sea is a terminal hypersaline lake located in one of the tectonic depressions formed along the Dead Sea transform (Neev and Emery 1967; Garfunkel 1997). The Dead Sea drainage basin comprises both Mediterranean and arid climatic zones. The size and shape of the Dead Sea drainage basin remained unchanged throughout the late Pleistocene and the Holocene, $\sim 40,000 \mathrm{~km}^{2}$ (Bentor 1961). The area consists mainly of Jurassic to Eocene carbonates, marls, and cherts. Neogene and Quaternary basalts are exposed in the north (Galilee and Golan Heights), covering $\sim 6500 \mathrm{~km}^{2}$.

Water sources into the modern Dead Sea are perennial streams, flash floods, and groundwater (fresh and saline). The Jordan River, which is the main freshwater source into the Sea of Galilee and subsequently into the Dead Sea, gets its water from several springs that emerge from calcitic, dolomite, 
and basaltic aquifers, mainly of Mount Hermon and the Golan Heights. The Dead Sea receives its water from the Sea of Galilee (by the southern Jordan River), the Yarmouk River, numerous small tributaries and springs, and runoff that drains from the Judean and Moab mountains (Figure 1). Lake Lisan - the last Glacial precursor of the Dead Sea-extended during its highest stand (26-19 kyr BP) from the Sea of Galilee in the north to the northern Arava Valley in the south, receiving large amounts of freshwater from Judean Desert runoff and the Sea of Galilee (Stein et al. 1997; Bartov et al. 2003; Hazan et al. 2005).

\section{MATERIALS AND ANALYTICAL METHODS}

Rain samples were collected in plastic funnels placed at the time of rainstorm initiation at 2 locations: 1) the roof of the Earth Sciences building at the Givat Ram campus of the Hebrew University in Jerusalem, and 2) the village of Eshtaol located $20 \mathrm{~km}$ west of Jerusalem. Incipient runoff waters, collected shortly after rain hits the ground, were collected in various locations across the western flank of the Judea watershed. Judean Desert floods were sampled in the vicinity of the modern Dead Sea shore. Water samples from perennial streams were collected during winter and summer. All samples were poisoned with $1 \%$ saturated $\mathrm{HgCl}_{2}$ and kept in standard brown ember glass bottles until analyzed.

Sixteen rain samples, 11 incipient runoff samples, 13 flood samples, and 14 perennial stream samples (of these, 3 were collected close to the source spring and therefore are denoted "spring" in Table 1) were collected over the course of the years 2000-2005. All samples were analyzed for their major ion composition, alkalinity, and DIC. Of these, 8 rain samples, 4 incipient runoff samples, 6 flood samples, and 14 perennial stream samples were analyzed for ${ }^{14} \mathrm{C}$ and $\delta^{13} \mathrm{C}$. In addition, 6 Dead Sea samples were analyzed for ${ }^{14} \mathrm{C}$ content.

Chemical analyses included alkalinity, DIC, $\mathrm{Ca}^{2+}, \mathrm{Mg}^{2+}, \mathrm{K}^{+}, \mathrm{Na}^{+}, \mathrm{Sr}^{2+}, \mathrm{Cl}^{-}, \mathrm{SO}_{4}{ }^{2-}, \delta^{13} \mathrm{C}$, and ${ }^{14} \mathrm{C}$. Alkalinity was determined by titration with $0.02 \mathrm{~N} \mathrm{HCl}$ using the Gran method for calculations. DIC was determined manometrically by the acid extraction method described by Barkan et al. (2001). The extracted $\mathrm{CO}_{2}$ was flame-sealed in ampoules and kept for ${ }^{14} \mathrm{C}$ and $\delta^{13} \mathrm{C}$ measurements. $\delta^{13} \mathrm{C}_{\mathrm{DIC}}$ analysis and graphitization of $\mathrm{CO}_{2}$ collected for ${ }^{14} \mathrm{C}_{\mathrm{DIC}}$ measurements were done at the Kimmel Center of the Weizmann Institute of Science. ${ }^{14} \mathrm{C}$ accelerator mass spectrometry (AMS) analyses were done at the NSF-Arizona AMS laboratory in Tucson.

Chemical compositions were measured at the Geological Survey of Israel (GSI). Cations $\left(\mathrm{Ca}^{2+}\right.$, $\left.\mathrm{Mg}^{2+}, \mathrm{K}^{+}, \mathrm{Na}^{+}, \mathrm{Sr}^{2+}\right)$ were analyzed by inductively coupled plasma atomic emission spectroscopy (ICP-AES; PerkinElmer Optima 3300) with $\sim 1 \%$ analytical precision. Anions $\left(\mathrm{Cl}^{-}, \mathrm{SO}_{4}{ }^{2-}\right)$ were analyzed with a Dionex 4000i ion chromatograph; analytical precision was less than $3 \%$.

\section{RESULTS}

${ }^{14} \mathrm{C}$ data, carbon isotopes, and chemical compositions of the samples are listed in Table 1 . The various flood profile groups (rain, incipient runoff, and floods) have distinct carbon isotopic and chemical compositions, although some overlap was observed. Rain waters have extremely low ionic strength, and scatter in the range of $43-85 \mathrm{pMC}$ in ${ }^{14} \mathrm{C}_{\mathrm{DIC}}$ and $-4.1 \%$ to $-10 \%$ in $\delta^{13} \mathrm{C}_{\text {DIC }}$. Incipient runoff waters have higher ionic strength; their average alkalinity was $1.4 \pm 0.8 \mathrm{meq} / \mathrm{L}(1 \sigma)$, and the $\mathrm{Ca}^{2+}+\mathrm{Mg}^{2+}-\mathrm{SO}_{4}{ }^{2-}$ (the calcium and magnesium corrected for gypsum dissolution) was in the range of $0.40-1.85 \mathrm{mmol} / \mathrm{L}$. The average ${ }^{14} \mathrm{C}$ content of these waters was $103 \pm 6 \mathrm{pMC}(1 \sigma)$, higher than those of rainwater. Floodwaters have a chemical composition similar to incipient runoff, but lower ${ }^{14} \mathrm{C}$ values, averaging $85 \pm 8 \mathrm{pMC}(1 \sigma)$. 


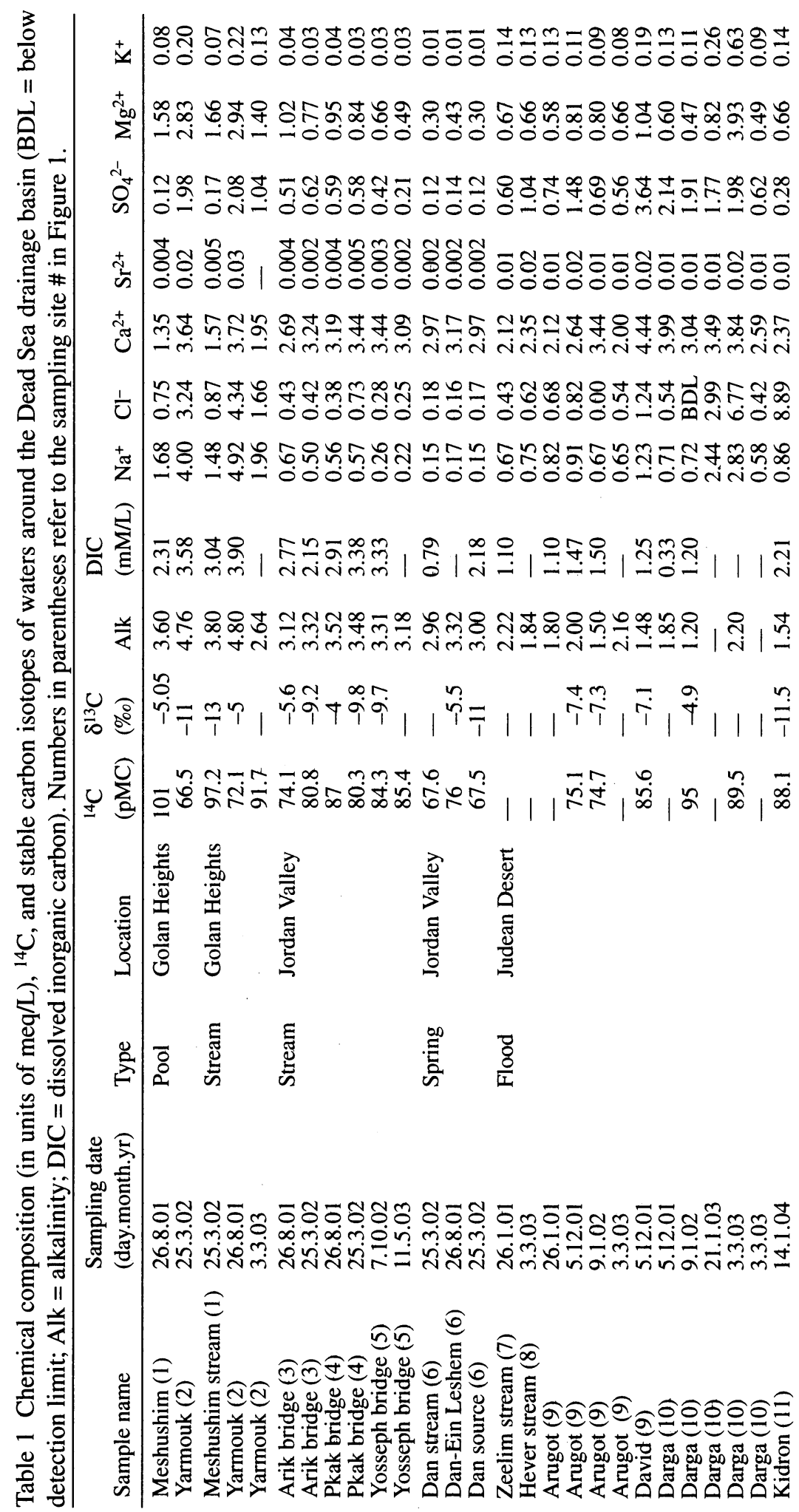




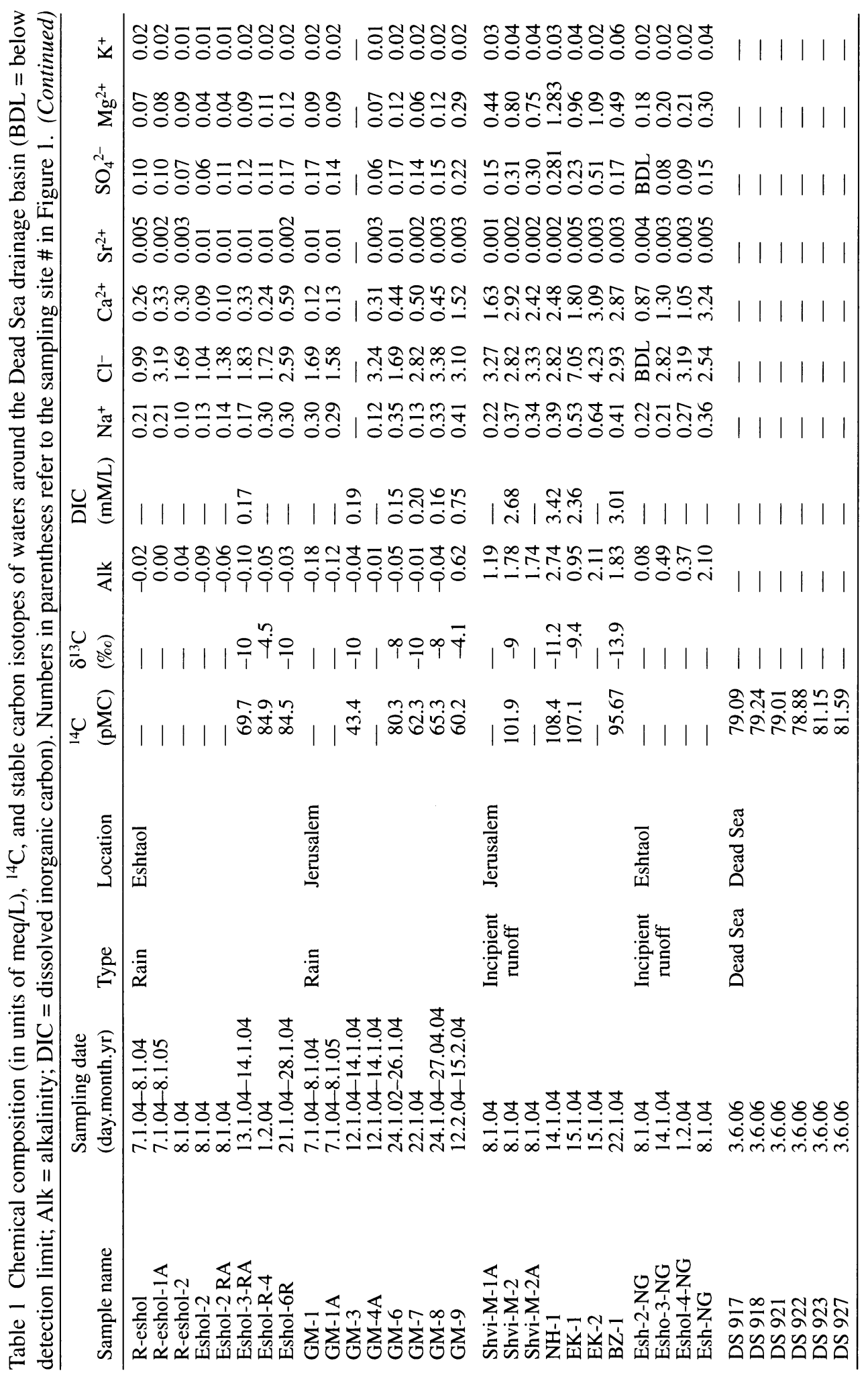



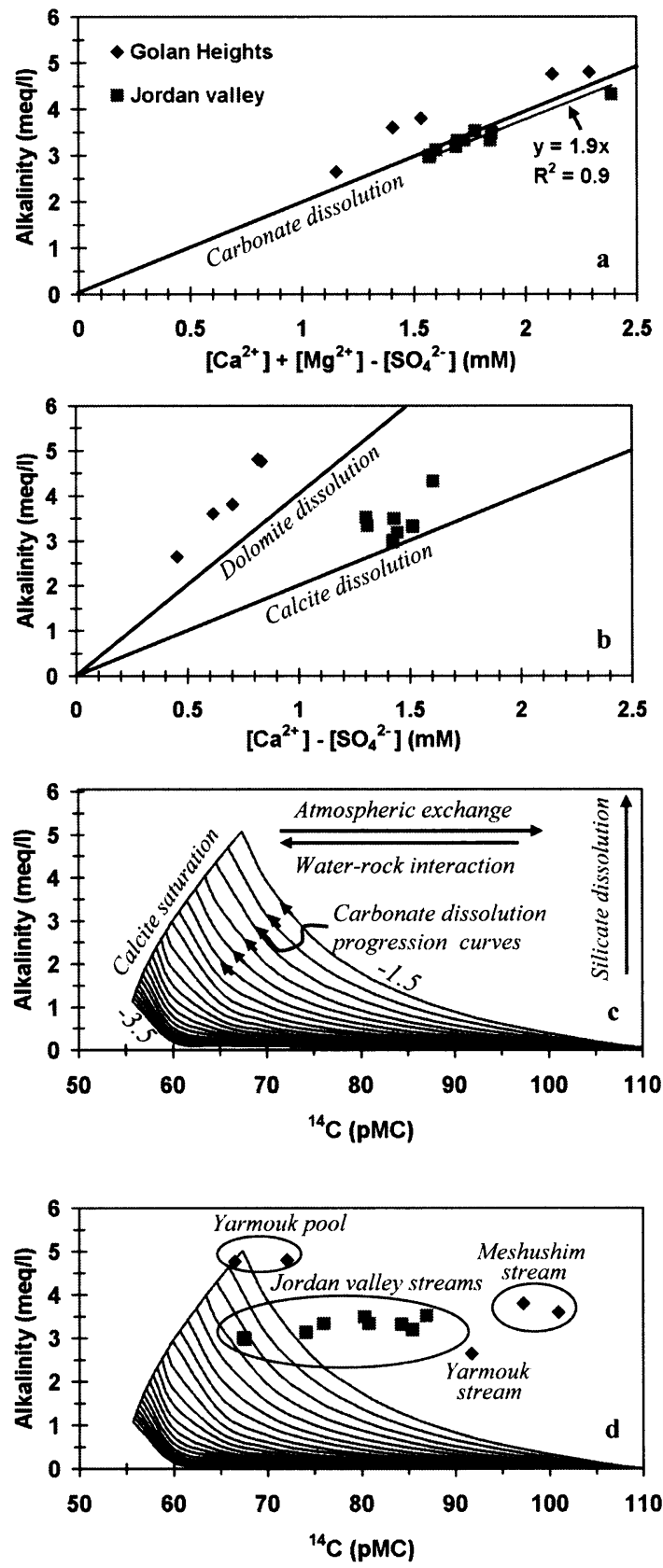

Figure 2 Trends of alkalinity as a function of $\mathrm{Ca}^{2+}+\mathrm{Mg}^{2+}-\mathrm{SO}_{4}{ }^{2-}(\mathrm{a}), \mathrm{Ca}^{2+}-\mathrm{SO}_{4}{ }^{2-}$ (b), and ${ }^{14} \mathrm{C}_{\mathrm{DIC}}$ (c) during dissolution of carbonates. Trends of constant $\mathrm{pCO}_{2}$ in the alkalinity vs. ${ }^{14} \mathrm{C}_{\mathrm{DIC}}$ field (c) were calculated assuming that the ${ }^{14} \mathrm{C}$ value of the $\mathrm{CO}_{2}$ gas dissolved in the water is $110 \mathrm{pMC}$, the ${ }^{14} \mathrm{C}$ of the dissolved carbonate is $0 \mathrm{pMC}$, and the resulting ${ }^{14} \mathrm{C}_{\mathrm{DIC}}{ }$ is a closed-system mixture of both, depending only on $\mathrm{pCO}_{2}$. The $\mathrm{pCO}_{2}$ of the upper and lower lines (soil $\mathrm{pCO}_{2}$ of $10^{-1.5} \mathrm{~atm} / \mathrm{L}$ and atmospheric $\mathrm{pCO}_{2}$ of $10^{-3.5} \mathrm{~atm} / \mathrm{L}$, respectively) are indicated in the figure and each line represents a $\mathrm{pCO}_{2}$ that differs by $10^{-0.1} \mathrm{~atm} / \mathrm{L}$. All constant $\mathrm{pCO}_{2}$ lines are terminated at calcite saturation, which was calculated after Holland (1979). Dissolution and precipitation at the same rate with a net of 0 will yield a ${ }^{14} \mathrm{C}_{\mathrm{DIC}}$ reduction beyond the calcite saturation curve. Data of perennial streams from the Golan Heights and Jordan Valley are presented in (a) and (b) and ${ }^{14} \mathrm{C}$ data is given in (d). Note that all Jordan Valley streams fall on the carbonate dissolution line (a), but they dissolved a mixture of calcite and dolomite because they fall between both lines (b); their horizontal spread in (d) indicates that they exchanged $\mathrm{CO}_{2}$ with the atmosphere (see text). Golan Heights streams fall above the carbonate and dolomite dissolution lines ( $a$ and $b$ ), indicating that they also have dissolved basaltic minerals. 
The chemical composition and ${ }^{14} \mathrm{C}$ content of perennial streams of the Jordan River were distinctly different than those of the Golan Heights streams. Jordan River samples had nearly constant alkalinity, averaging $3.25 \pm 0.2 \mathrm{meq} / \mathrm{L}$, while the Golan Heights waters show large variations in the range of 2.65 and $4.80 \mathrm{meq} / \mathrm{L}$. The ${ }^{14} \mathrm{C}$ content of Jordan River perennial streams ranges between $67-87$ pMC, while Golan Heights streams indicate $2{ }^{14} \mathrm{C}$ groups: $\sim 100$ and $\sim 70$ pMC.

\section{DISCUSSION}

Analysis of ${ }^{14} \mathrm{C}$, stable carbon isotopes, and the chemical composition of the waters in the Dead Sea drainage basin allows us to determine the main processes controlling the ${ }^{14} \mathrm{C}$ composition of Lake Lisan waters. The main processes we consider here are water-rock interaction and the exchange of ${ }^{1+} \mathrm{C}\left(\right.$ as ${ }^{14} \mathrm{CO}_{2}$ ) between water and atmosphere. Plots of alkalinity versus $\mathrm{Ca}^{2+}+\mathrm{Mg}^{2+}$, and $\mathrm{Ca}^{2+}$ (after subtracting the $\mathrm{SO}_{4}{ }^{2-}$ to correct for $\mathrm{Ca}^{2+}$ gain due to gypsum dissolution) are distinctive for carbonate dissolution (Figure 2a) and the type of carbonate phase dissolved (i.e. calcite or dolomite; Figure $2 \mathrm{~b}$ ). The ${ }^{14} \mathrm{C}_{\mathrm{DIC}}$-alkalinity relationship of the water during carbonate dissolution depends on the $\mathrm{pCO}_{2}$ as shown in alkalinity versus ${ }^{14} \mathrm{C}_{\mathrm{DIC}}$ plots (Figure $2 \mathrm{c}$ ). Different trend lines, each representing constant $\mathrm{pCO}_{2}$, were calculated assuming that the $\mathrm{CO}_{2}$ dissolved in the water while infiltrating into the soils (and acquiring the soils' $\mathrm{pCO}_{2}$ ) yields ${ }^{14} \mathrm{C}_{\mathrm{DIC}}$ content similar to the modern atmospheric ${ }^{14} \mathrm{C}$ composition. Vectors representing silicate dissolution, $\mathrm{CO}_{2}$ exchange between the water and the atmosphere, and carbonate dissolution are distinctive in the alkalinity versus ${ }^{14} \mathrm{C}$ field (Figure 2c).

\section{Dissolution Reactions and Carbon Isotopes in the Perennial Streams}

Plotting of the perennial stream data in Figure 2 shows that the chemical composition of the Jordan Valley and Golan Heights streams is controlled by the different lithologies of these regions. The chemistry of Jordan Valley streams that flow over carbonate terrains containing rich carbonate soils (Neaman et al. 1999) show carbonate (calcite and dolomite) dissolution. Relating the chemistry of Golan Heights streams with the mineralogical composition of Golan Heights basalts (Weinstein 1998), and the sum of all dissolution reaction products, reveals interaction between the streams and the basalts exposed in the area (Figure 2a,b). An alkalinity versus ${ }^{14} \mathrm{C}$ plot reveals an additional difference between the Jordan Valley and the Golan Heights springs (Figure 2d). While the Jordan Valley streams lie along a single trend in this diagram, indicating a ${ }^{14} \mathrm{C}_{\mathrm{DIC}}$ increase due to atmospheric exchange, the Golan Heights springs show no clear trend. The importance of atmospheric exchange in controlling the Jordan Valley streams' ${ }^{14} \mathrm{C}_{\mathrm{DIC}}$ is supported by the $\delta^{13} \mathrm{C}-{ }^{14} \mathrm{C}$ relationship (Figure 3). Waters that interacted with atmospheric $\mathrm{CO}_{2}$ and soil $\mathrm{CO}_{2}$ yielded similar ${ }^{14} \mathrm{C}_{\text {DIC }}$ values, but different $\delta^{13} \mathrm{C}$ values. The plot shows that during winter, the streams are close to the vector representing $\mathrm{CO}_{2}$ exchange with the atmosphere (increase of both ${ }^{14} \mathrm{C}$ and $\delta^{13} \mathrm{C}$ ). This probably reflects the highly turbulent winter flows. On the other hand, during summer the streams lie close to the vector representing exchange with soil $\mathrm{CO}_{2}$ (increase in ${ }^{14} \mathrm{C}_{\mathrm{DIC}}$ and decrease in $\delta^{13} \mathrm{C}_{\mathrm{DIC}}$ ), probably reflecting the sluggish flow on the soil cover (Figure 3).

The higher ${ }^{14} \mathrm{C}$ content of the Jordan River as compared to its source spring (e.g. $\Delta^{14} \mathrm{C}_{\mathrm{DIC}}$ between Dan source and Arik bridge is 23 pMC according to Carmi et al. [1985], and 13 pMC in this study; see Table 1 and Figure 1) supports the idea that $\mathrm{CO}_{2}$ exchange with the atmosphere resulted in ${ }^{14} \mathrm{C}_{\text {DIC }}$ increase.

The intensity of ${ }^{14} \mathrm{C}$ water-atmospheric exchange remained constant since the mid-1980s as indicated by the consistency in the atmospheric exchange fraction. This fraction $(E$ in Equation 1$)$ is a measure of how much the ${ }^{14} \mathrm{C}$ content of the main river has become closer to the atmospheric ${ }^{14} \mathrm{C}$ 


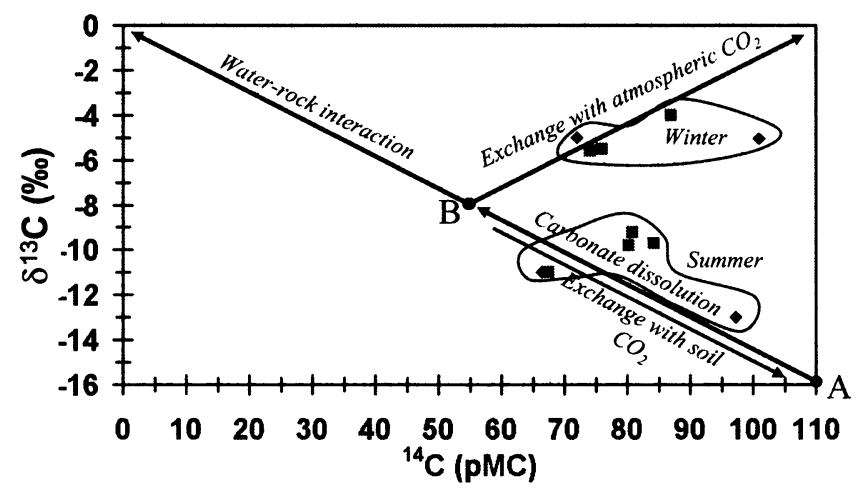

Figure $3 \delta^{13} \mathrm{C}$ vs. ${ }^{14} \mathrm{C}_{\mathrm{DIC}}$ of perennial streams (legend is the same as in Figure 2). The directions of 4 vectors representing dissolution and precipitation of carbonates with a net of 0 (water-rock interaction); exchange with atmospheric $\mathrm{CO}_{2}$; dissolution of carbonate rocks; and exchange with soils' $\mathrm{CO}_{2}$ is given for explanation. The dissolution vector was constructed assuming a closed system in which half of the DIC generated during dissolution is rock derived (here taken as $0 \mathrm{pMC}$ ) and half is of atmospheric origin (here taken as $110 \mathrm{pMC}$ ). The solid black circles represent hypothetical water that dissolved soil $\mathrm{CO}_{2}\left(\mathrm{~A} ;-16 \%\right.$ was considered as representing the average $\delta^{13} \mathrm{C}$ of a water sample in isotopic equilibrium with soil $\mathrm{CO}_{2}$ ) and then dissolved "dead" carbonate rocks until reaching calcite saturation (B). Note that during winter, the streams are close to the vector representing exchange with atmospheric $\mathrm{CO}_{2}$. This is probably due to the turbulent flow of winter floods. In contrast, during slower summer flows the streams follow the vector representing exchange with soil $\mathrm{CO}_{2}$. The plot clearly indicates that, besides dissolution of "dead" carbonates, the perennial springs did not interact further with the terrain carbonate rocks (there are no points in the direction of the vector representing water-rock interaction).

value, as compared to the ${ }^{14} \mathrm{C}$ content of its tributaries (water sources). $E$ is defined by the equation (Carmi et al. 1985):

$$
E=\frac{X_{j r d}-X_{t r b}}{X_{a t m}-X_{t r b}}
$$

where $X_{j r d}$ is the ${ }^{14} \mathrm{C}_{\mathrm{DIC}}$ value of the Jordan River (the value at Arik bridge); $X_{t r b}$ is the ${ }^{14} \mathrm{C}_{\mathrm{DIC}}$ value of the Jordan tributaries (the value at Dan source); and $X_{a t m}$ is the atmospheric ${ }^{14} \mathrm{C}$ value of a specific year (here taken as $106 \mathrm{pMC}$, the value for the year 2002 as estimated by the empirical relationship given in Levin and Kromer [1997]). The equation above indicates that the values of $E$ may vary between 0 (no atmospheric exchange) and 1 (total atmospheric exchange). The winter value of $E$ is 0.35 (see Table 1 for data), very similar to its value in the mid-1980s of $0.36 \pm 0.02$ (Carmi et al. 1985). This means that about $1 / 3$ of the DIC in the tributaries was exchanged with the atmosphere, and that the hydrological conditions have not changed during the last $20 \mathrm{yr}$. It should be noted that $E$ being a fraction allows for comparing atmospheric exchange intensity over that period, despite the observed decrease in atmospheric ${ }^{14} \mathrm{C}$.

\section{The Chemical and Radiocarbon Evolution of Floods}

The evolution of runoff water from rain to incipient runoff and finally to floods is revealed in its chemical and ${ }^{14} \mathrm{C}$ compositions (Figure 4). We suggest that, although evolution of floods in the Dead Sea drainage basin is accompanied by continuous dissolution of carbonate rocks (Figure $4 \mathrm{a}, \mathrm{b}$ ), the ${ }^{14} \mathrm{C}$ content of the floodwater is mainly determined by the extent of $\mathrm{CO}_{2}$ exchange with the atmosphere (Figure 4c). Rainwater follows the lower constant $\mathrm{pCO}_{2}$ curves (Figure 4c), suggesting that rains gained their initial ${ }^{14} \mathrm{C}_{\mathrm{DIC}}$ from dissolution of airborne carbonate particles in the open atmosphere. This is expected when considering the high dust flux in the Dead Sea drainage basin $\left(90-120 \mathrm{~g} \mathrm{~cm}^{2}\right.$ 
$\mathrm{yr}^{-1}$; Ganor and Foner 1996) and the high content of carbonates in average Israel dust (45\%; Ganor and Mamane 1982). The evolution of rain to incipient runoff is accompanied by an alkalinity and ${ }^{14} \mathrm{C}_{\text {DIC }}$ increase (Figure $4 \mathrm{c}$ ), probably because additional carbonate dissolution and ${ }^{14} \mathrm{CO}_{2}$ exchange occurs in the high $\mathrm{pCO}_{2}$ soil environment. During the transition from incipient runoff to fully developed floods, ${ }^{14} \mathrm{C}$ content is lowered while alkalinity remains constant (Figure $4 \mathrm{c}$ ). Although dissolution and precipitation at the same rate with a net of 0 may have caused the observed ${ }^{14} \mathrm{C}$ decrease with no effect on the alkalinity (see vector in Figure 2), we think that the observed variability in ${ }^{14} \mathrm{C}_{\mathrm{DIC}}$ content of the floods may be explained by the variability in the extent of exchange with atmospheric $\mathrm{CO}_{2}$. We base this suggestion on $\delta^{13} \mathrm{C}_{\text {DIC }}$ data (discussed below), flood ${ }^{14} \mathrm{C}$ data (Table 1), and on the difference in the pattern of streams (wadis) that currently drain into the Dead Sea.
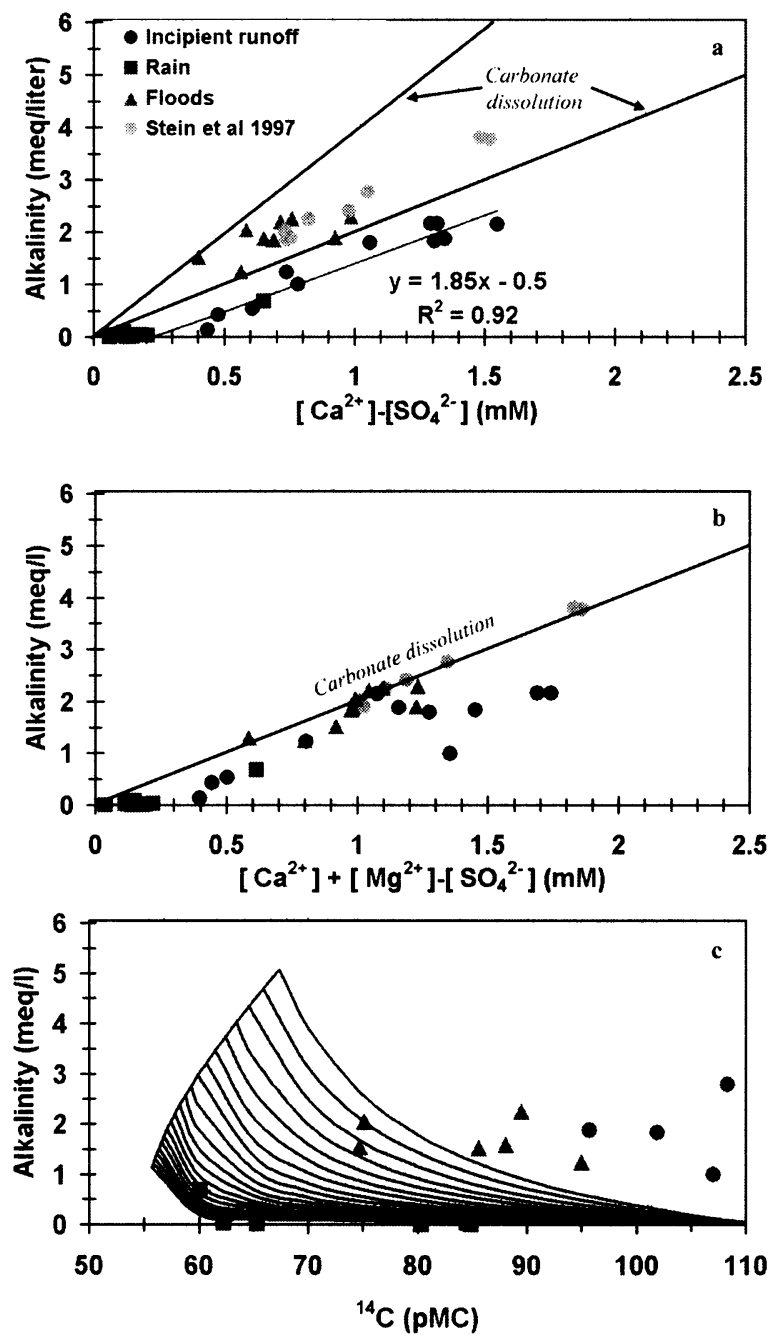

Figure 4 Alkalinity as a function of $\mathrm{Ca}^{2+}-\mathrm{SO}_{4}{ }^{2-}$ (a), $\mathrm{Ca}^{2+}+\mathrm{Mg}^{2+}-\mathrm{SO}_{4}{ }^{2-}(\mathrm{b})$, and ${ }^{14} \mathrm{C}_{\text {DIC }}$ (c) during flood evolution from rain to incipient runoff and finally to fully developed floods. Note that the best fit to the incipient runoff waters in (b) is parallel but below the dissolution line of calcite. The offset of the trend line is $-0.5 \mathrm{meq} / \mathrm{L}$ and crosses the $x$ axis at the rainwater cluster. This is because most rainwater has negative alkalinity, i.e. excess acidity that is titrated by the dissolved calcite. While the first carbonate dissolved was calcite, floods fall between the calcite and dolomite dissolution lines, indicating a mixture of the two. For comparison, earlier floodwater data follow the same trend (Stein et al. 1997).

Three closely located wadis that drain their floodwaters directly into the Dead Sea (Arugot, David, and Darga; Figure 1) yielded different ${ }^{14} \mathrm{C}_{\text {DIC }}$ values (Table 1). The Arugot wadi floods yielded a rather low ${ }^{14} \mathrm{C}$ content of $\sim 75 \mathrm{pMC}$, while Darga floods yielded a high ${ }^{14} \mathrm{C}$ content of $\sim 90-95 \mathrm{pMC}$. The David and Kidron wadis showed intermediate values of 86 and 88 pMC, respectively. The 
lithology and vegetation cover are similar in all 3 wadis, as well as their drainage basin areas and the total flood flow distances (e.g. drainage basin areas are 230 and $232 \mathrm{~km}^{3}$ for Darga and Arugot, respectively). Thus, the observed ${ }^{14} \mathrm{C}$ variability between the floods might be related to another factor. We suggest that the ${ }^{14} \mathrm{C}$ change is related to the shape of the active part of the wadis' alluvial fan deltas (Figure 5). While the Arugot fan delta (with low ${ }^{14} \mathrm{C}_{\mathrm{DIC}}$ ) was artificially channeled, the Darga fan delta (with high ${ }^{14} \mathrm{C}_{\mathrm{DIC}}$ ) was kept in its wide and shallow natural shape. Judean Desert floods initiate in narrow rock channels and spread over a large area when reaching the fan delta. The flood changes from a low surface area to depth ratio in the channels to a high ratio in the fan deltas. A high surface area to depth ratio facilitates gas exchange with the atmosphere, and hence elevates the flood ${ }^{14} \mathrm{C}_{\mathrm{DIC}}$. In contrast, Wadi Arugot floods that are channeled all the way to the Dead Sea have a smaller gas-exchange area, and hence smaller atmospheric imprint on the ${ }^{14} \mathrm{C}_{\mathrm{DIC}}$, which remains low. A similar situation was observed in flows over gravel terrains where high surface area to depth ratio of the flowing water resulted in high ${ }^{14} \mathrm{C}$ content, as compared with flows over the bedrock terrain (Broecker and Walton 1959).

Figure 5 Aerial photos of Arugot (a), David (b), and Darga (c) fan deltas. The channeling of the Arugot stream and the differences in the active part

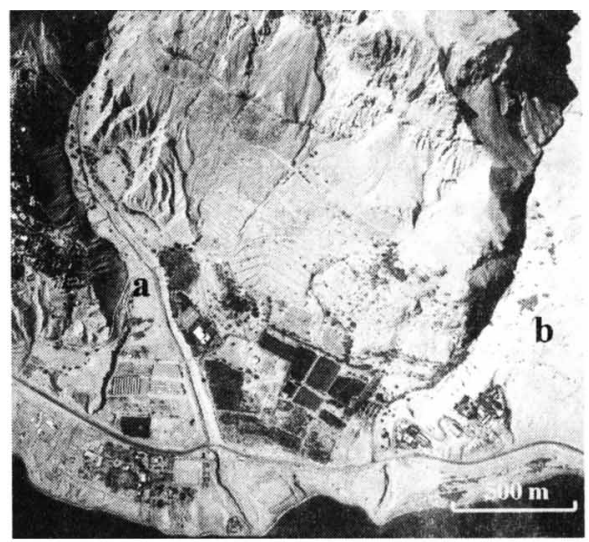
of the fan delta surface areas are evident.

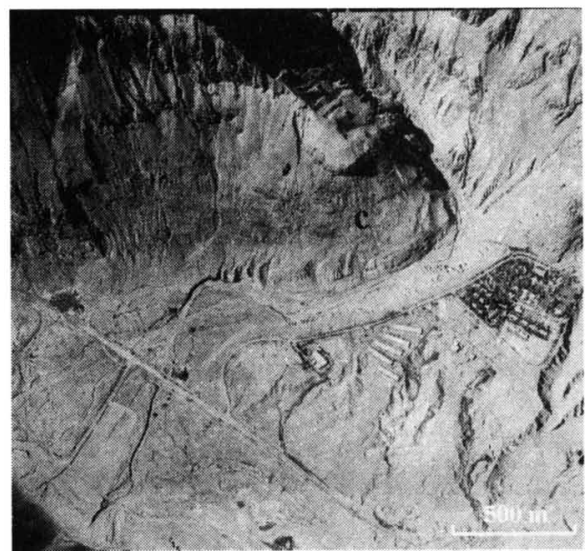

The evolution of floods from rain is seen also in DIC versus ${ }^{14} \mathrm{C}_{\mathrm{DIC}}$ and $\delta^{13} \mathrm{C}_{\mathrm{DIC}}$ versus ${ }^{14} \mathrm{C}_{\mathrm{DIC}}$ plots (Figure 6). During the evolution from rain to incipient runoff, water ${ }^{14} \mathrm{C}_{\mathrm{DIC}}$ increase is accompanied by DIC increase (Figure 6a) and $\delta^{13} \mathrm{C}_{\mathrm{DIC}}$ decrease (Figure 6b). These observations suggest addition of isotopically "light" soil $\mathrm{CO}_{2}$, which also has a modern (high) ${ }^{14} \mathrm{C}$ content. When incipient runoffs evolve to floods, the opposite trends are observed (Figure 6), probably due to $\mathrm{CO}_{2}$ escape (when water exits the high $\mathrm{pCO}_{2}$ soil) accompanied by water-rock exchange. In summary, the main process 
controlling the ${ }^{14} \mathrm{C}_{\mathrm{DIC}}$ content during the flood evolutionary path is exchange with ${ }^{14} \mathrm{CO}_{2}$ in the atmosphere (soil atmosphere and open-air atmosphere alike).
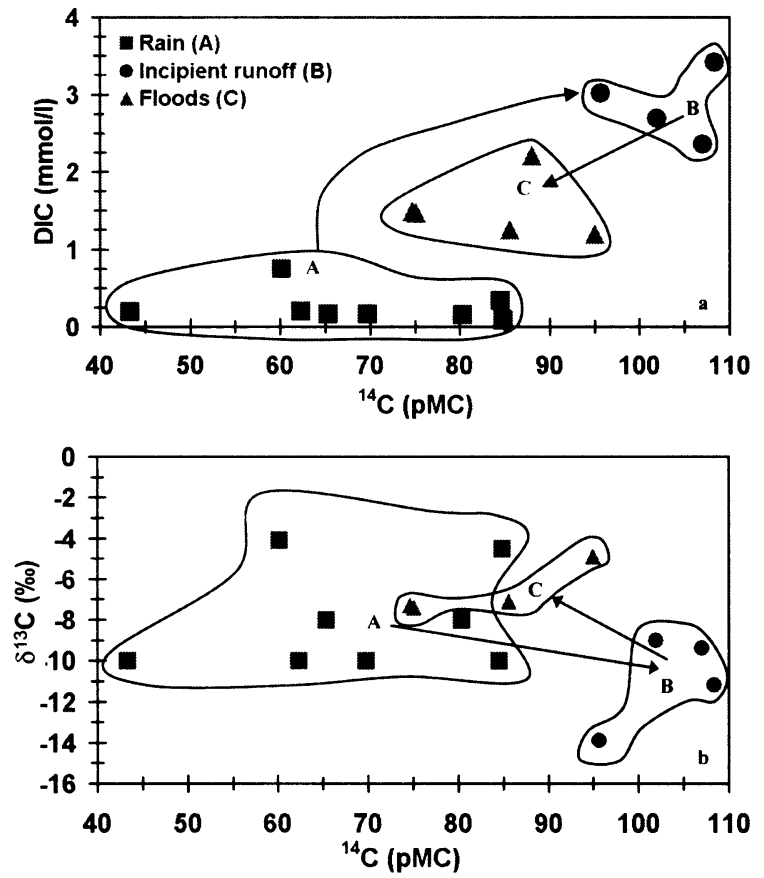

Figure $6{ }^{14} \mathrm{C}$ (in pMC) vs. DIC (a) and vs. $\delta^{13} \mathrm{C}(\mathrm{b})$ during flood evolution. The clusters and arrows define water composition boundaries and development direction from rain to incipient runoff and floods.

\section{Paleohydrological Implications}

The evidence we present from the modern Dead Sea drainage basin indicates that exchange with atmospheric ${ }^{14} \mathrm{CO}_{2}$ is a major process controlling the ${ }^{14} \mathrm{C}$ content of the various water sources in the basin, and hence determines the reservoir age of the Dead Sea and its precursor, Lake Lisan. Below, we explain the $1.6 \pm 0.3 \mathrm{kyr}$ reservoir age of Lake Lisan (calculated from pairs of primary aragonite laminae and organic debris collected from the same stratigraphic horizons of the Lisan Formation; Stein et al. 2004) in view of these processes and a mass balance between the various ${ }^{14} \mathrm{C}$ and water sources (Table 2).

Table $2{ }^{14} \mathrm{C}$ values and reservoir ages of waters in the Dead Sea drainage area.

\begin{tabular}{llll}
\hline Water source & $\begin{array}{l}{ }^{14} \mathrm{C} \\
(\mathrm{pMC})\end{array}$ & $\begin{array}{l}\text { Reservoir age } \\
(\mathrm{kyr})\end{array}$ & Reference \\
\hline Lake Lisan & $80-85$ & $1.6 \pm 0.3$ & Stein et al. 2004 \\
Modern Dead Sea (2003) & $80 \pm 1.1$ & 2.3 & This study \\
Northern Jordan River & $80-92$ & $1.1-2.3$ & This study; Stiller et al. 2001 \\
Sea of Galilee & 95 & 0.8 & Hazan et al. 2005; Lev et al. 2007 \\
Flash floods (not channeled) & $85-95$ & $1.0-1.3$ & This study \\
Channeled flash floods (Arugot) & 75 & 2.9 & This study \\
Fresh groundwater & $50-58$ & $5-6.2$ & Yechieli et al. 1996; Lewenberg 2005 \\
Saline groundwater & $5-10$ & $19-25$ & This study; Yechieli et al. 1996 \\
\hline
\end{tabular}


$\mathrm{Sr} / \mathrm{Ca}$ and ${ }^{87} \mathrm{Sr} /{ }^{86} \mathrm{Sr}$ ratios in Lake Lisan aragonites were used to estimate the most likely fractions of different water sources that supplied the lake with bicarbonate (Stein et al. 1997). Two different mixtures of water sources were suggested: a) 0.2 Sea of Galilee waters, $\sim 0.8$ flood waters, and $\sim 0.05$ brine waters; and b) $\sim 0.2-0.5$ northern Jordan River waters, $\sim 0.5-0.8$ flood waters, and $\sim 0.04$ brine waters. In both mixtures, the contribution of fresh groundwater to the total water mass balance was considered negligible (Stein et al. 1997). From the aforementioned fractions, we calculated the weighted ${ }^{14} \mathrm{C}$ content $\left({ }^{14} C_{\text {weighted }}\right.$ ) of Lake Lisan (see also values of flash floods, Sea of Galilee, and Jordan River in Table 2) as follows:

$$
{ }^{14} C_{\text {weighted }}=f_{\text {SOG-J }} \times{ }^{14} C_{\text {SOG-J }}+\left(1-f_{\text {SOG-J }}\right) \times{ }^{14} C_{\text {flood }}=\left(f_{\text {SOG-J }} \times{ }^{14} C_{\text {SOG-J }}\right)+\left(f_{\text {flood }} \times{ }^{14} C_{\text {flood }}\right)
$$

Where the subscript $S O G-J$ denotes either the Sea of Galilee or northern Jordan River; $f_{i}$ denotes the fraction of water source $i ;{ }^{14} C_{S O G-J}$ denotes the ${ }^{14} \mathrm{C}$ content (in pMC) of source $J$; and ${ }^{14} C_{\text {flood }}$ denotes the ${ }^{14} \mathrm{C}$ content of Judean Desert floods.

The reservoir age (RA) was calculated from ${ }^{14} C_{\text {weighted }}$ by rearranging the age equation:

$$
R A=-\frac{1}{\lambda_{14}} \ln \frac{{ }^{14} C_{\text {weighted }}}{{ }^{14} C_{\text {atmosphere }}}
$$

where $\lambda_{14}$ is the decay constant of ${ }^{14} \mathrm{C}\left(1.21 \times 10^{-4} \mathrm{yr}^{-1}\right)$ and ${ }^{14} C_{\text {atmosphere }}$ is the atmospheric ${ }^{14} \mathrm{C}$ content. A value of $106 \mathrm{pMC}$ was assigned when relating to "modern" samples. This value was empirically estimated by Levin and Kromer (1997) as the atmospheric ${ }^{14} \mathrm{C}$ content in the year 2002, when the samples for the present study were collected.

Substituting into Equation 2, the ${ }^{14} \mathrm{C}$ composition of the Sea of Galilee and Judean Desert floods (not channeled), according to the Lake Lisan water mass balance presented above, yielded a Lisan RA of $1.3 \pm 0.3$, which is slightly lower than the observed value.

During the Lisan period, runoff input into the lake was about 6-fold higher than present natural values (Barkan et al. 2001). Under the existing hydrological conditions, such an increase in runoff discharge would have increased flow turbulence, and hence enhanced atmospheric exchange, yielding Lake Lisan RA values lower than those actually measured. Yet, the Lisan time was characterized by enhanced accumulation of dust on the Judean Mountains bedrocks (e.g. Frumkin and Stein 2004). This would have caused additional carbonate dissolution, resulting in an RA increase in the floods. Furthermore, during the high stand of Lake Lisan, the fan deltas of the wadis flowing to the Dead Sea were completely or partially submerged (Bartov et al. 2002). Because $\mathrm{CO}_{2}$ exchanges efficiently with the atmosphere when the water resides in the fan deltas, limiting the flood flow to the rock-lined channels will lead to a $\mathrm{CO}_{2}$ exchange reduction and consequently to an RA increase.

Other factors that could increase the RA are the following:

- Aging within the lake's reservoir: Talma et al. (1997) demonstrated that a short-term decrease in the ${ }^{14} \mathrm{C}$ content of the modern Dead Sea surface water is attributed to contribution of old, deep water. However, previous studies have shown that the aragonite deposition in Lake Lisan was annual (Prasad et al. 2004) and that the contribution of brine (where aging can occur) was negligible (Stein et al. 1997). Accordingly, aging within the lake reservoir is considered unlikely.

- Contribution of saline springs: The ${ }^{14} \mathrm{C}$ content of saline springs entering the modern Dead Sea is very low, approaching $0 \mathrm{pMC}$ (Yechieli et al. 1996). Thus, they could potentially increase the RA. However, although not negligible, the contribution of the saline springs to the water budget of the lake is rather small (Machlus 1996; Stein et al. 1997). 
In summary, the Sea of Galilee, the Dead Sea, and Lake Lisan maintained uniform and specific RAs of $0.8 \pm 0.1,2.3 \pm 0.1$, and 1.6 \pm 0.3 , respectively (Stein et al. 2004; Bookman et al. 2007; Lev et al. 2007). The discrepancy between the measured and the calculated RA of Lake Lisan may reflect enhanced dissolution of carbonantic dust, changes in the amount of ${ }^{14} \mathrm{C}$ exchanged in Judean Desert floods, or variations in the contribution of brine and saline springs. Furthermore, the small fluctuations in the Lisan RA $(1.6 \pm 0.3)$ may reflect short-term, small modifications in the relative contributions of these sources.

\section{CONCLUSION}

Carbon isotopic and chemical compositions of modern Dead Sea water sources (e.g. northern Jordan River water; Judean Mountains rain-runoff-flood waters) were used to determine the processes that controlled the ${ }^{14} \mathrm{C}$ reservoir age in the Holocene Dead Sea and the late Pleistocene Lake Lisan.

The results of this study point towards the importance of $\mathrm{CO}_{2}$ exchange with the atmosphere on the ${ }^{14} \mathrm{C}$ content of runoff waters. The northern Jordan River waters rapidly gain a high ${ }^{14} \mathrm{C}$ content, increasing from $67 \mathrm{pMC}$ in its feed to Hermon Mountain springs to $\sim 85 \mathrm{pMC}$ in the river. Judean Mountains waters increase their ${ }^{14} \mathrm{C}$ content from $\sim 43-80 \mathrm{pMC}$ in rain to $\sim 95-108 \mathrm{pMC}$ in incipient runoff. In addition, the ${ }^{14} \mathrm{C}$ content of Judean Mountains floods is probably affected by geomorphological differences in flood flow patterns, i.e. the flow over fan deltas versus channels influences the $\mathrm{CO}_{2}$ exchange rate.

The late Quaternary lakes along the Jordan Valley-Dead Sea basin (i.e. the Sea of Galilee, the Holocene Dead Sea, and the late Pleistocene Lake Lisan) display relatively uniform and specific RA values of $0.8 \pm 0.1,2.3 \pm 0.1$, and $1.6 \pm 0.3$, respectively.

The higher RA values of the Dead Sea and Lake Lisan compared to the Sea of Galilee reflect a more moderate ${ }^{14} \mathrm{C}$ atmospheric exchange rate of their water sources, as well as dissolution of dust particles and possibly a minor contribution of saline springs.

\section{ACKNOWLEDGMENTS}

We wish to thank Mariana Stiller for her insightful comments, Orit Sivan for helping in the field and laboratory work and for her useful comments, Haim Hemo for sampling floods, and the laboratory technicians at the Israel Geological Survey for helping in analyzing the samples. This research was funded by the Israel Science Foundation (ISF) grant number 250/03 (BL).

\section{REFERENCES}

Barkan E, Luz B, Lazar B. 2001. Dynamics of the carbon dioxide system in the Dead Sea. Geochimica et Cosmochimica Acta 65(3):355-68.

Bartov Y, Stein M, Enzel Y, Agnon A, Reches Z. 2002. Lake levels and sequence stratigraphy of Lake Lisan, the late Pleistocene precursor of the Dead Sea. Quaternary Research 57(1):9-21.

Bartov Y, Goldstein SL, Stein M, Enzel Y. 2003. Catastrophic arid episodes in the eastern Mediterranean linked with the North Atlantic Heinrich events. Geology 31(5):439-42.

Bentor YK. 1961. Some geochemical aspects of the Dead Sea and the question of its age. Geochimica et Cosmochimica Acta 25(4):239-60.
Bookman R, Lazar B, Stein M, Burr GS. 2007. Radiocarbon dating of primary aragonite by sequential extraction of $\mathrm{CO}_{2}$. The Holocene 17(1):131-7.

Broecker WS, Walton A. 1959. The geochemistry of ${ }^{14} \mathrm{C}$ in fresh-water systems. Geochimica et Cosmochimica Acta 16(1-3):15-38.

Carmi I, Stiller M, Kaufman A. 1985. The effect of atmospheric ${ }^{14} \mathrm{C}$ variations on the ${ }^{14} \mathrm{C}$ levels in the Jordan River system. Radiocarbon 27(2B):305-13.

Frumkin A, Stein M. 2004. The Sahara-East Mediterranean dust and climate connection revealed by strontium and uranium isotopes in a Jerusalem speleothem. Earth and Planetary Science Letters 217(3-4):45164. 
Ganor E, Foner HA. 1996. The mineralogical and chemical properties and the behaviour of Aeolian Saharan dust over Israel. In: Guerzoni S, Chester R, editors. The Impact of Desert Dust Across the Mediterranean. Dordrecht: Kluwer Academic. p 163-72.

Ganor E, Mamane Y. 1982. Transport of Saharan dust across the eastern Mediterranean. Atmospheric Environment $16(3): 581-7$.

Garfunkel Z. 1997. The history and formation of the Dead Sea basin. In: Niemi TM, Ben-Avraham Z, Gat JR, editors. The Dead Sea: The Lake and Its Setting. Oxford: Oxford University Press. p 36-56.

Hazan N, Stein M, Agnon A, Marco S, Nadel D, Negendank JFW, Schwab MJ, Neev D. 2005. The late Quaternary limnological history of Lake Kinneret (Sea of Galilee), Israel. Quaternary Research 63(1):60-77.

Holland DH. 1979. The Chemistry of the Atmosphere and Oceans. New York: John Wiley \& Sons. 369 p.

Lev L, Boaretto E, Heller J, Marco S, Stein M. 2007. The feasibility of using Melanopsis shells as radiocarbon chronometers, Lake Kinneret, Israel. Radiocarbon, these proceedings.

Levin I, Kromer B. 1997. Twenty years of atmospheric ${ }^{14} \mathrm{CO}_{2}$ observations at Schauinsland station, Germany. Radiocarbon 39(2):205-18.

Lewenberg O. 2005. The hydrogeology and geochemistry of groundwater in the alluvial fan of Wadi Arugot, En Gedi reservation [MSc thesis]. Jerusalem: Hebrew University of Jerusalem. In Hebrew.

Machlus M. 1996. Geochemical parameters in the Lisan Formation aragonite-proxies for paleolimnology of Lake Lisan and climatic history of the Dead Sea region [MSc thesis]. Jerusalem: Hebrew University of
Jerusalem. In Hebrew.

Neaman A, Singer A, Stahr K. 1999. Clay mineralogy as affecting disaggregation in some palygorskite containing soils of the Jordan and Bet-She'an valleys. Australian Journal of Soil Research 37(5):913-28.

Neev D, Emery KO. 1967. The Dead Sea: Depositional Processes and Environments of Evaporates. Jerusalem: Geological Survey of Israel Bulletin 41. $147 \mathrm{p}$.

Prasad S, Vos H, Negendank JFW, Waldmann N, Goldstein SL, Stein M. 2004. Evidence from Lake Lisan of solar influence on decadal- to centennial-scale climate variability during marine oxygen isotope stage 2 . Geology 32(7):581-4.

Stein M, Starinsky A, Katz A, Goldstein SL, Machlus M, Schramm A. 1997. Strontium isotopic, chemical, and sedimentological evidence for the evolution of Lake Lisan and the Dead Sea. Geochimica et Cosmochimica Acta 61(18):3975-92.

Stein M, Migowski C, Bookman R, Lazar B. 2004. Temporal changes in radiocarbon reservoir age in the Dead Sea-Lake Lisan system. Radiocarbon 46(2):649-55.

Talma AS, Vogel JC, Stiller M. 1997. The radiocarbon content of the Dead Sea. In: Niemi TM, Ben-Avraham Z, Gat JR, editors. The Dead Sea: The Lake and Its Setting. Oxford: Oxford University Press. p 193-8.

Weinstein YS. 1998. Mechanisms of generation of intracontinental alkali-basalt in northern Israel $[\mathrm{PhD}$ dissertation]. Jerusalem: Hebrew University of Jerusalem.

Yechieli Y, Ronen D, Kaufman A. 1996. The source and age of groundwater brines in the Dead Sea area, as deduced from ${ }^{36} \mathrm{Cl}$ and ${ }^{14} \mathrm{C}$. Geochimica et Cosmochimica Acta 60(11):1909-16. 